\title{
Hormetic Responses of Photosystem II in Tomato to Botrytis cinerea
}

\author{
Maria-Lavrentia Stamelou ${ }^{1,2}$, Ilektra Sperdouli ${ }^{2} \mathbb{D}$, Ioanna Pyrri ${ }^{3} \mathbb{D}$, Ioannis-Dimosthenis S. Adamakis ${ }^{1}$ \\ and Michael Moustakas $4, *$ (D)
}

1 Section of Botany, Department of Biology, National and Kapodistrian University of Athens, GR-15784 Athens, Greece; marilorast@yahoo.gr (M.-L.S.); iadamaki@biol.uoa.gr (I.-D.S.A.)

2 Institute of Plant Breeding and Genetic Resources, Hellenic Agricultural Organization-Demeter, Thermi, GR-57001 Thessaloniki, Greece; ilektras@bio.auth.gr

3 Section of Ecology \& Systematics, Department of Biology, National and Kapodistrian University of Athens, GR-15784 Athens, Greece; ipyrri@biol.uoa.gr

4 Department of Botany, Aristotle University of Thessaloniki, GR-54124 Thessaloniki, Greece

* Correspondence: moustak@bio.auth.gr

check for updates

Citation: Stamelou, M.-L.; Sperdouli, I.; Pyrri, I.; Adamakis, I.-D.S.;

Moustakas, M. Hormetic Responses of Photosystem II in Tomato to Botrytis cinerea. Plants 2021, 10, 521. https://doi.org/10.3390/ plants10030521

Academic Editor: Hazem M. Kalaji

Received: 1 February 2021

Accepted: 7 March 2021

Published: 10 March 2021

Publisher's Note: MDPI stays neutral with regard to jurisdictional claims in published maps and institutional affiliations.

Copyright: (c) 2021 by the authors. Licensee MDPI, Basel, Switzerland. This article is an open access article distributed under the terms and conditions of the Creative Commons Attribution (CC BY) license (https:// creativecommons.org/licenses/by/ $4.0 /)$.

\begin{abstract}
Botrytis cinerea, a fungal pathogen that causes gray mold, is damaging more than 200 plant species, and especially tomato. Photosystem II (PSII) responses in tomato (Solanum lycopersicum L.) leaves to Botrytis cinerea spore suspension application were evaluated by chlorophyll fluorescence imaging analysis. Hydrogen peroxide $\left(\mathrm{H}_{2} \mathrm{O}_{2}\right)$ that was detected $30 \mathrm{~min}$ after Botrytis application with an increasing trend up to $240 \mathrm{~min}$, is possibly convening tolerance against $B$. cinerea at short-time exposure, but when increasing at relative longer exposure, is becoming a damaging molecule. In accordance, an enhanced photosystem II (PSII) functionality was observed 30 min after application of $B$. cinerea, with a higher fraction of absorbed light energy to be directed to photochemistry $\left(\Phi_{P S I I}\right)$. The concomitant increase in the photoprotective mechanism of non-photochemical quenching of photosynthesis (NPQ) resulted in a significant decrease in the dissipated non-regulated energy $\left(\Phi_{N O}\right)$, indicating a possible decreased singlet oxygen $\left({ }^{1} \mathrm{O}_{2}\right)$ formation, thus specifying a modified reactive oxygen species (ROS) homeostasis. Therefore, $30 \mathrm{~min}$ after application of Botrytis spore suspension, before any visual symptoms appeared, defense response mechanisms were triggered, with PSII photochemistry to be adjusted by NPQ in a such way that PSII functionality to be enhanced, but being fully inhibited at the application spot and the adjacent area, after longer exposure (240 $\mathrm{min}$ ). Hence, the response of tomato PSII to B. cinerea, indicates a hormetic temporal response in terms of "stress defense response" and "toxicity", expanding the features of hormesis to biotic factors also. The enhanced PSII functionality $30 \mathrm{~min}$ after Botrytis application can possible be related with the need of an increased sugar production that is associated with a stronger plant defense potential through the induction of defense genes.
\end{abstract}

Keywords: biotic stress; reactive oxygen species (ROS); photoprotection; non-photochemical quenching (NPQ); hormesis; hydrogen peroxide $\left(\mathrm{H}_{2} \mathrm{O}_{2}\right)$; photosynthesis; toxicity; stress defense; chlorophyll fluorescence imaging

\section{Introduction}

Botrytis cinerea, a fungal pathogen that causes gray mold, is damaging more than 200 plant species, especially tomato, cucumber, strawberry, potato, and ornamental plants [1,2]. $B$. cinerea releases ethylene to accelerate leaf wither, decreasing photosynthetic efficiency and affecting plant production resulting in huge economic losses [2,3]. This pathogen kills plant tissues previous to feeding on them, and uses a variety of toxic molecules to decompose the host cells $[4,5]$. Symptoms initial develop on infected tissues as limited lesions that subsequently become necrotic and spread to other tissues [5]. Thus, lesion development induced by the necrotrophic fungus $B$. cinerea influences growth performance 
of tomato plants [6]. Sugars produced by plants, although beneficial for the pathogen as nutrient source, are often associated with stronger plant defense potential, through their involvement in the induction of phenylpropanoids and/or defense genes [7]. Infection by $B$. cinerea induces increased respiration on the infected tissues, leading to a severe drop in the $\mathrm{O}_{2}$ concentration in an otherwise fully aerobic leaf [8].

In plant cellular metabolism, and especially in chloroplasts, reactive oxygen species (ROS) are continuously produced at basal levels that are incapable to cause damage, as they are being scavenged by different antioxidant mechanisms [9-12]. However, under most biotic or abiotic stresses an increased production of ROS occurs that can lead to oxidative stress if it is not scavenged by enzymatic or non-enzymatic antioxidants [11-15]. However, ROS derived from the chloroplasts also play a role in plant resistance against $B$. cinerea [15].

ROS, such as superoxide anion radical $\left(\mathrm{O}_{2}{ }^{\bullet-}\right)$, hydrogen peroxide $\left(\mathrm{H}_{2} \mathrm{O}_{2}\right)$, and singlet oxygen $\left({ }^{1} \mathrm{O}_{2}\right)$, produced in chloroplasts play dual roles as they generate oxidative stress and also confer essential biological function as redox signaling in response to biotic and abiotic stress conditions [14-16]. The role of chloroplast antioxidants, that often have overlying or interrelating functions, is not to totally eliminate ROS, but rather to achieve a suitable balance between production and removal so that to counterpart photosynthetic function, permitting an effective diffusion of signals to the nucleus and adjusting a plethora of physiological functions $[13,16,17]$. Leaf image analysis is also used as an objective and accurate alternative method to quantify ROS production at the affected leaf areas, and has proven to be a useful tool in plant science [15].

Photosynthesis is a fundamental process in plant physiology, and its regulation plays a central role in plant defense against biotic and abiotic stresses $[18,19]$. Photosynthesis studies seem incomplete without some chlorophyll fluorescence data, since minor modifications in plant metabolism make this technique appropriate to provide insight into plant-stress interaction [18-24]. Chlorophyll fluorescence analysis has been extensively used to uncover perturbations on the photosynthetic efficiency due to nutrient deficiency, drought stress, soil salinity, metal toxicity, wastewater toxicity, pathogenic diseases, etc. [25-33]. The development of the method of chlorophyll fluorescence imaging analysis (CF-IA) permits the revealing of the leaf spatiotemporal photosynthetic heterogeneity at the total leaf surface, that is ignored when measuring chlorophyll fluorescence with the classical point measurement techniques [18,20-23]. CF-IA is a highly effective non-invasive method for the estimation of the inhibition or damage in the PSII electron transfer process, serving as an extremely sensitive indicator of photosynthetic efficiency under both biotic and abiotic stress conditions [24,34-39]. The fact that biotic stresses are typically heterogeneous, being spatiotemporal, renders chlorophyll fluorescence imaging apparatuses powerful tools to study the impact of biotic stress on leaf photosynthetic performance [37].

Plants respond to biotic and abiotic stresses by a plethora of mechanisms [13,40]. A low-level of stress or a short exposure duration has been frequently referred to stimulate plant performance $[13,20,40-44]$. This enhancement can be achieved through a basal level of ROS $[9,10,13,16,45]$, that is being regulated by the photoprotective mechanism of photosynthesis, the non-photochemical quenching (NPQ) [23,43,46]. NPQ under stress conditions decreases electron transport rate (ETR) to avoid ROS formation $[35,47]$. ROS production that can occur through PSII damage can prevent the repair of PSII reaction centres [35,48]. Dose-response studies are proposing hormesis as a widespread phenomenon usual in nature and independent of the kind of stressor, the physiological process or the organism it occurs $[13,40,43,44,49]$.

In the present work we used CF-IA to quantify the impact of $B$. cinerea spore suspension application on photosystem II (PSII) in tomato leaves, combined with ROS detection at the inoculated leaf area. We monitored the time-lapsed PSII functionality and try to gain an insight into the mechanisms that play a role in plant defense response to the fungal pathogen. 


\section{Results}

\subsection{Visible Symptoms of Botrytis cinerea Spore Application on Tomato}

Visual damage on tomato leaflets could be detected only after $24 \mathrm{~h}$ of the $20 \mu \mathrm{L}$ spore suspension application $\left(10^{5}-10^{7}\right.$ spores $/ \mathrm{mL}$ ) (Figure 1a), with the apparent hyphae formation to be also observed (Figure 1b). Leaflet damage appeared as a discoloration of the leaf epidermis (white spot) (arrow in Figure 1a).
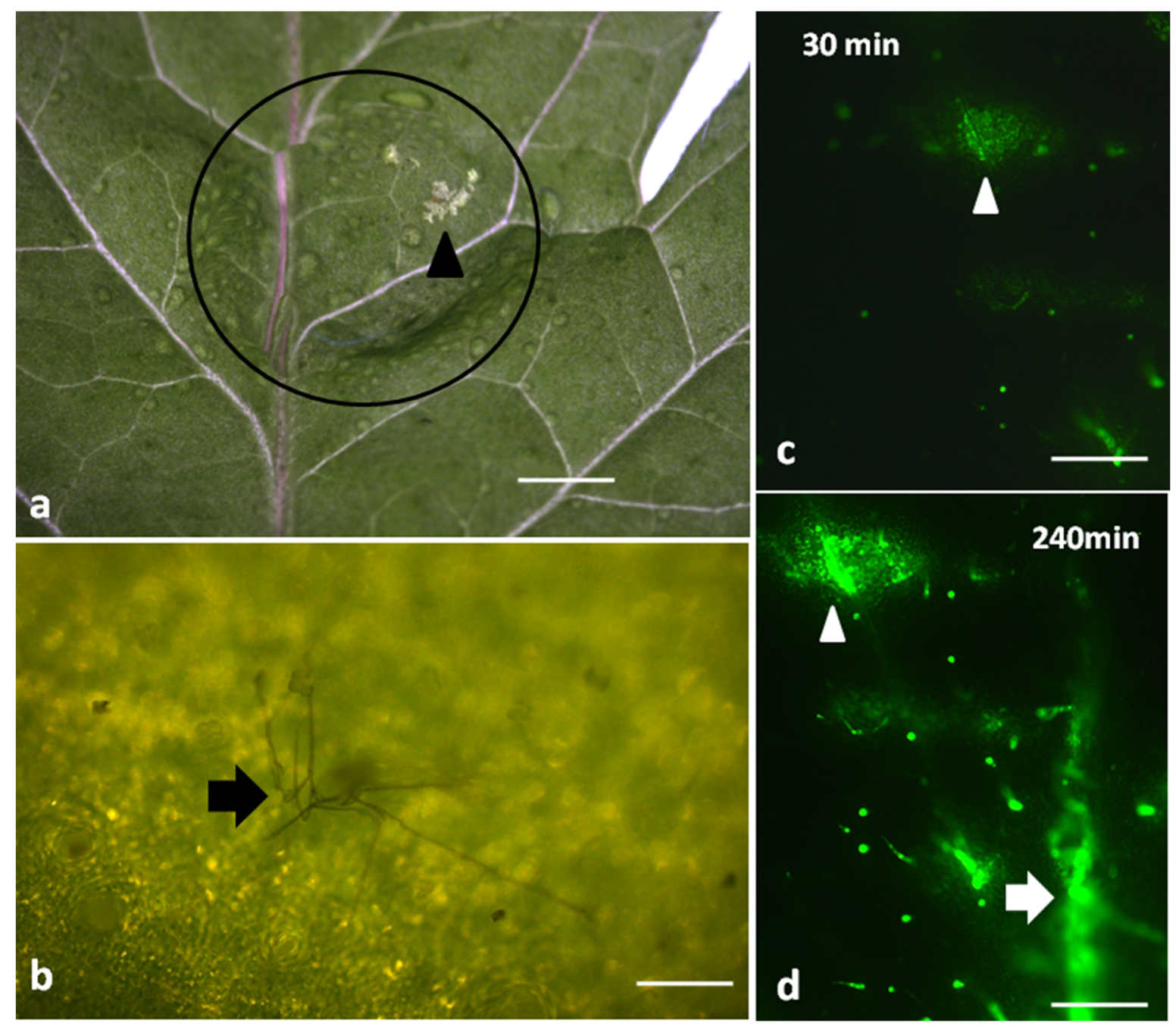

Figure 1. A visible damage (arrowhead) can be observed on a tomato leaf $24 \mathrm{~h}$ after application of a Botrytis cinerea spore suspension drop (circle) (a). B. cinerea hyphae (arrow) visible on the leaf epidermis $24 \mathrm{~h}$ after the spore suspension application (b). Staining of tomato leaflets with $2^{\prime}, 7^{\prime}$-dichlorofluorescein diacetate (DCF-DA) for hydrogen peroxide $\left(\mathrm{H}_{2} \mathrm{O}_{2}\right)$ detection after 30 (c) and $240 \mathrm{~min}$ (d) of B. cinerea application. Hydrogen peroxide generation is visible as green fluorescence (c,d). Scale Bars: $1 \mathrm{~mm}$ in (a), $0.2 \mathrm{~mm}$ in (b), and $500 \mu \mathrm{m}$ in (c,d).

\subsection{Hydrogen Peroxide Detection after Botrytis cinerea Spore Application}

At 30 min after $B$. cinerea spore suspension application, $\mathrm{H}_{2} \mathrm{O}_{2}$ production was detected at the drop's application area only (arrowhead in Figure 1c), but with time, $\mathrm{H}_{2} \mathrm{O}_{2}$ production gradually increased and spread out (Figure 1d). Thus, after 240 min, DCF-DA signal intensified in the application area (arrowhead in Figure 1d) and $\mathrm{H}_{2} \mathrm{O}_{2}$ detection expanded to the leaf veins as well (arrow in Figure 1d). 


\subsection{Allocation of Absorbed Light Energy at PSII before and after Spore Application}

We estimated the fraction of the absorbed light energy that is used for photochemistry $\left(\Phi_{\mathrm{PSII}}\right)$, is lost by regulated heat dissipation $\left(\Phi_{\mathrm{NPQ}}\right)$, and that of non-regulated energy loss $\left(\Phi_{N O}\right)$, that add up to unity [35]. The effective quantum yield of PSII photochemistry ( $\left.\Phi_{\text {PSII }}\right) 30 \mathrm{~min}$ after spore suspension application increased significantly compared to control, while $120 \mathrm{~min}$ after spore suspension application it did not differ compared to control, at both LL and HL treatments. $\Phi_{\mathrm{PSII}}$ decreased significantly compared to control, 240 min after spore suspension application, at both LL and HL (Figure 2). The quantum yield of regulated non-photochemical energy loss in PSII $\left(\Phi_{\mathrm{NPQ}}\right)$ increased significantly up to $120 \mathrm{~min}$ after spore suspension application, but later on decreased to control level at LL (Figure 3a), while at HL treatment there was no significant difference compared to control at all measurements after spore suspension application (Figure $3 b$ ).

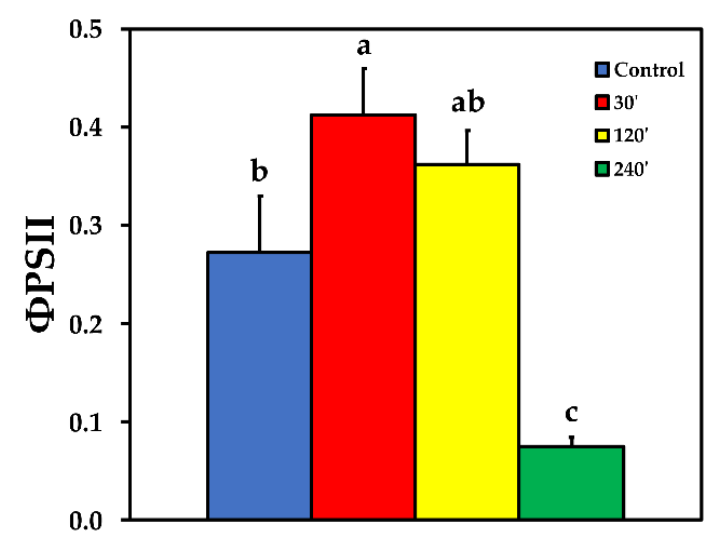

(a)

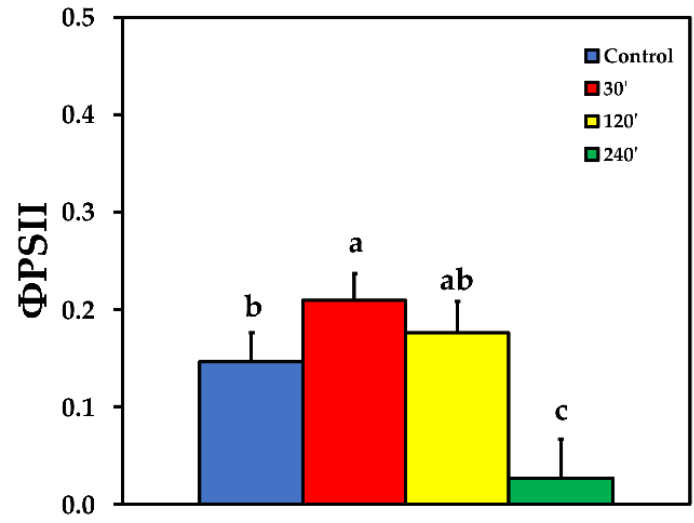

(b)

Figure 2. The effective quantum yield of PSII photochemistry ( $\Phi_{\text {PSII }}$ ) before (control) and after 30, 120 and $240 \mathrm{~min}$ of $B$. cinerea aquatic spore suspension application on tomato leaflets, measured at $230 \mu \mathrm{mol}$ photons m ${ }^{-2} \mathrm{~s}^{-1}$ (a), and at $900 \mu \mathrm{mol}$ photons $\mathrm{m}^{-2} \mathrm{~s}^{-1}(\mathbf{b})$. Error bars are standard deviations $(\mathrm{n}=6)$. Columns with different letters are statistically different $(p<0.05)$.

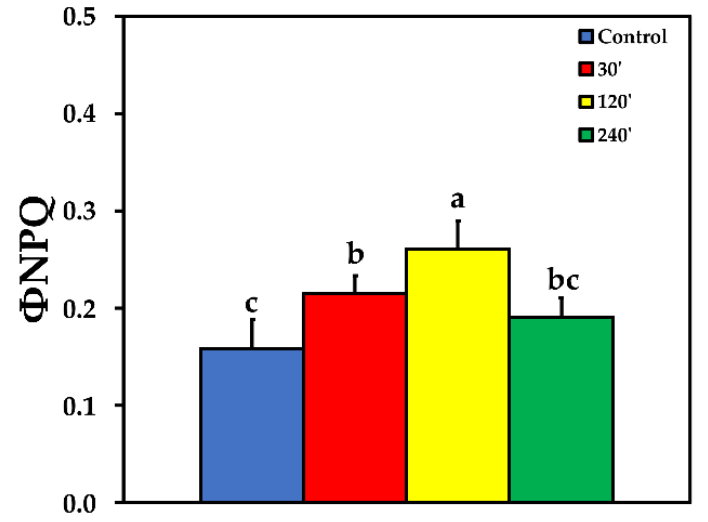

(a)

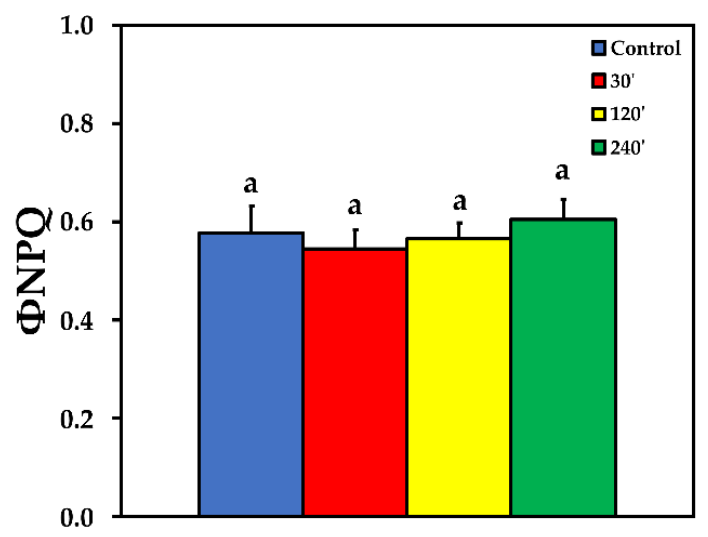

(b)

Figure 3. The quantum yield of regulated non-photochemical energy loss in PSII ( $\left.\Phi_{\mathrm{NPQ}}\right)$ before (control) and after 30, 120

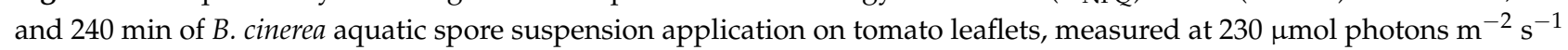
(a), and at $900 \mu \mathrm{mol}$ photons $\mathrm{m}^{-2} \mathrm{~s}^{-1}(\mathbf{b})$. Error bars are standard deviations $(\mathrm{n}=6)$. Columns with different letters are statistically different $(p<0.05)$. 
Due to the increase of $\Phi_{\mathrm{NPQ}}$ at 30 and $120 \mathrm{~min}$ after spore suspension application, the quantum yield of non-regulated energy loss in PSII $\left(\Phi_{\mathrm{NO}}\right)$ decreased compared to control, but increased significantly $240 \mathrm{~min}$ after spore suspension application at LL (Figure 4a). At $\mathrm{HL}$, the pattern was similar to LL, with the exception that of $120 \mathrm{~min}$ after spore suspension application, where $\Phi N O$ was at the same level with control plants (Figure $4 b$ ).

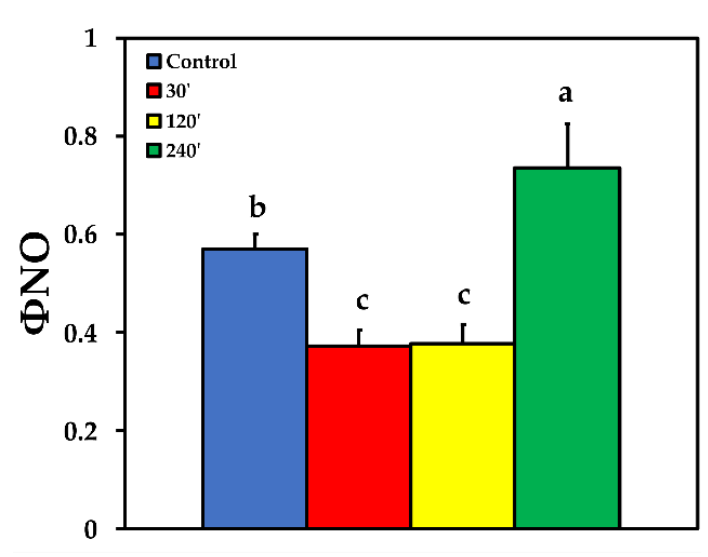

(a)

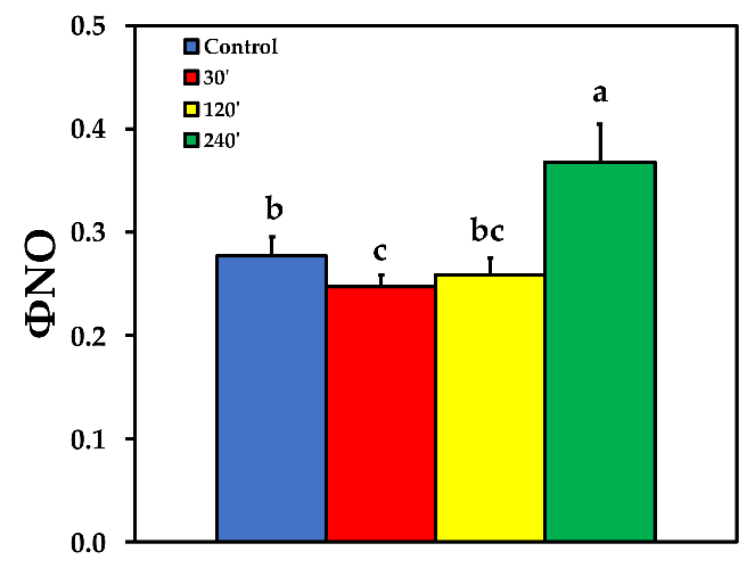

(b)

Figure 4. The quantum yield of non-regulated energy loss in PSII ( $\left.\Phi_{\mathrm{NO}}\right)$ before (control) and after 30, 120 and $240 \mathrm{~min}$ of $B$. cinerea aquatic spore suspension application on tomato leaflets, measured at $230 \mu \mathrm{mol}$ photons $\mathrm{m}^{-2} \mathrm{~s}^{-1}$ (a), and at $900 \mu \mathrm{mol}$ photons $\mathrm{m}^{-2} \mathrm{~s}^{-1}(\mathbf{b})$. Error bars are standard deviations $(\mathrm{n}=6)$. Columns with different letters are statistically different $(p<0.05)$.

\subsection{Photoprotective Dissipation of Excitation Energy as Heat (NPQ)}

The non-photochemical chlorophyll fluorescence quenching (NPQ) increased significantly up to $120 \mathrm{~min}$ after spore application, but later on decreased to control level at LL (Figure 5a). At HL treatment, there was no significant difference compared to control, at 30 and $120 \mathrm{~min}$ after spore application, while at $240 \mathrm{~min}$ after spore application, NPQ was significantly lower than control (Figure $5 b$ ).

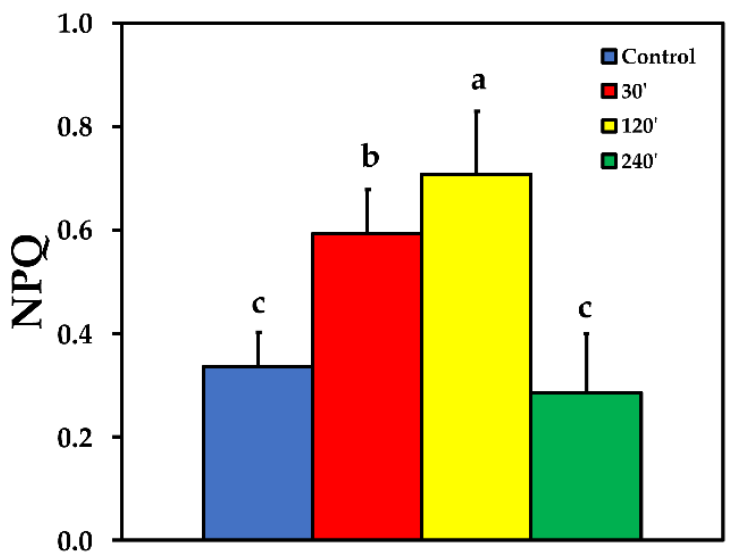

(a)

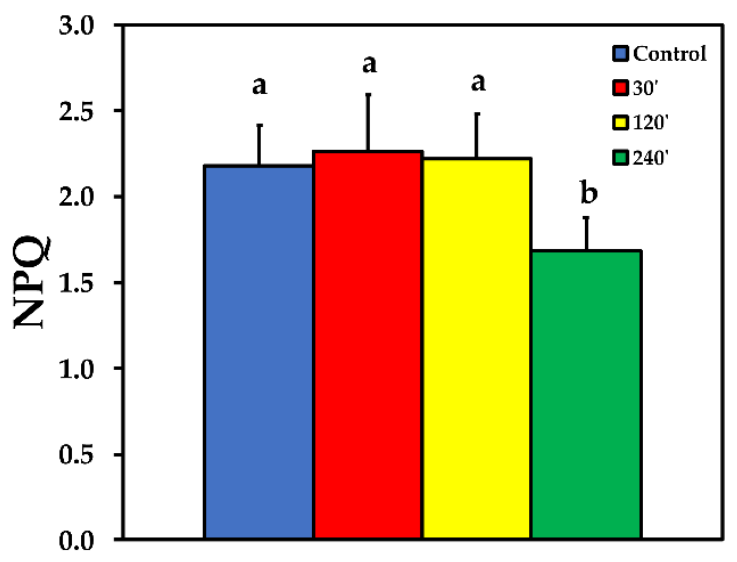

(b)

Figure 5. The non-photochemical quenching (NPQ), reflecting heat dissipation, before (control) and after 30, 120 and 240 min of $B$. cinerea aquatic spore suspensions application on tomato leaflets, measured at $230 \mu \mathrm{mol}$ photons $\mathrm{m}^{-2} \mathrm{~s}^{-1}$ (a), and at $900 \mu \mathrm{mol}$ photons $\mathrm{m}^{-2} \mathrm{~s}^{-1}(\mathbf{b})$. Error bars are standard deviations $(\mathrm{n}=6)$. Columns with different letters are statistically different $(p<0.05)$. 


\subsection{Chlorophyll a Fluorescence Images}

At $30 \mathrm{~min}$ after application of $B$. cinerea suspension, $\Phi_{\mathrm{PSII}}$ decreased in the direct vicinity of the spore application area, compared to control values (arrow in Figure 6). At the same time at the surrounding area and the rest of the leaflet, an increased $\Phi_{\mathrm{PSII}}$ was observed, having as a result a higher $\Phi_{\mathrm{PSII}}$ value at the whole leaflet compared to control. At $240 \mathrm{~min}$ after spore application, the effective quantum yield of PSII photochemistry was severely affected at the whole leaflet area, being totally interrupted $\left(\Phi_{\mathrm{PSII}}=0\right)$ at the application spot and the adjacent area, and on most of the leaflet, with a high photosynthetic heterogeneity to be observed (Figure 6).

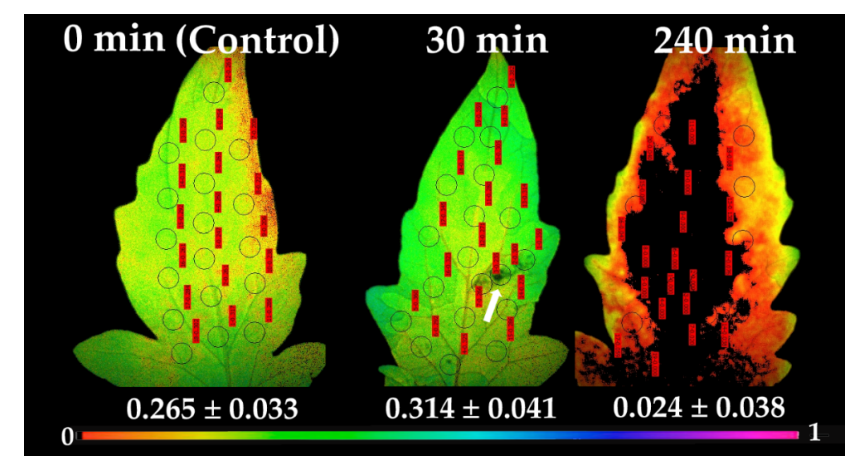

Figure 6. Chlorophyll fluorescence images of $\Phi_{\mathrm{PSII}}$, measured at $640 \mu \mathrm{mol}$ photons $\mathrm{m}^{-2} \mathrm{~s}^{-1}$, before ( 0 min, control) and after 30 and $240 \mathrm{~min}$ of $B$. cinerea suspension application on tomato leaflets. The color code depicted at the bottom ranges from values 0.0 to 1.0. The circles in each image denote the areas of interest (AOI) that were selected in each leaflet and are complemented by red labels with their $\Phi_{\text {PSII }}$ values, while whole leaflet value is presented. Arrowhead at $\Phi_{\text {PSII }}$ image after 30 min of B. cinerea suspension application points at the visible area of the aquatic spore suspensions.

Following the pattern of $\Phi_{\mathrm{PSII}}$, the redox state of the plastoquinone pool, that is a measure of the number of open PSII reaction centers $\left(q_{\mathrm{P}}\right), 30 \mathrm{~min}$ after spore suspension application increased at the whole leaflet ( $54 \%$ open), compared to control ( $44 \%$ open) (Figure 7). In accordance to $\Phi_{\text {PSII }}$ pattern, at $240 \mathrm{~min}$ after spore application, most reaction centers at the application spot and the adjacent area, were completely closed $\left(q_{\mathrm{P}}=0\right)$, and also on most of the leaflet, with only a $5 \%$ of reaction centers to remain open at the whole leaflet (Figure 7).

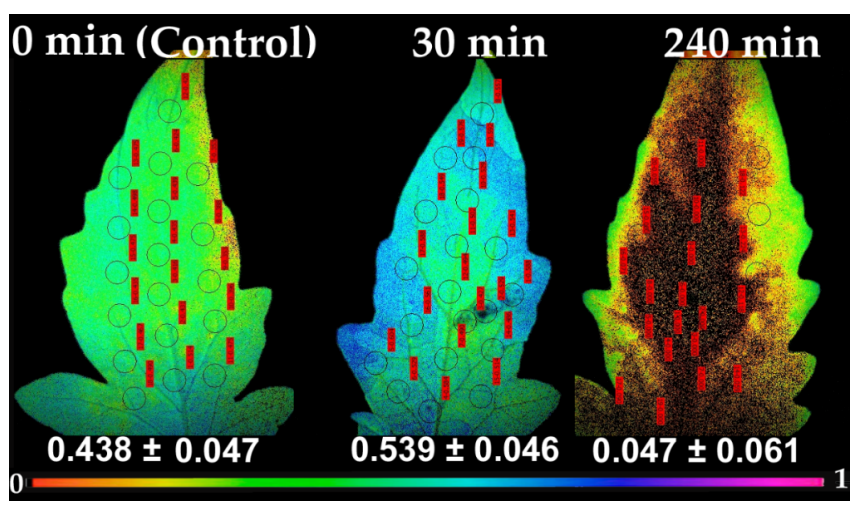

Figure 7. Chlorophyll fluorescence images of the fraction of open PSII reaction centers $\left(q_{\mathrm{P}}\right)$, measured at $640 \mu \mathrm{mol}$ photons $\mathrm{m}^{-2} \mathrm{~s}^{-1}$, before ( $0 \mathrm{~min}$, control) and after 30 and $240 \mathrm{~min}$ of B. cinerea spore suspension application on tomato leaflets. The color code depicted at the bottom ranges from values 0.0 to 1.0. The circles in each image denote the areas of interest (AOI) that were selected in each leaflet and are complemented by red labels with $q_{\mathrm{P}}$ values, while whole leaflet value is presented. 


\section{Discussion}

Plant pathogens are divided into biotrophics, that attack the host cells conserving host viability and gaining nutrients from living cells, and necrotrophics, that get their nutrients by killing the host plant [8]. Botrytis cinerea is a necrotrophic plant pathogen causing gray mold disease on several crop plant species, producing enormous damage in crop production [4]. Thus, there is increasing interest in the mechanism(s) utilized by plants to counteract infection by this fungus [8].

The necrotrophic pathogen $B$. cinerea is able to induce ROS generation, especially $\mathrm{H}_{2} \mathrm{O}_{2}$, in a plethora of plant species [50,51], either directly or indirectly (e.g., via the toxin botrydial) [52]. In our experimental set up, $\mathrm{H}_{2} \mathrm{O}_{2}$ was detected 30 min after spore suspension application and gradually increased (Figure 1). The question that arises is on the role of this $\mathrm{H}_{2} \mathrm{O}_{2}$ production. One possible explanation proposed from various researchers was that the $\mathrm{H}_{2} \mathrm{O}_{2}$ produced could directly fight off the fungi [51]. However, this hypothesis was abandoned since $\mathrm{H}_{2} \mathrm{O}_{2}$ production does not affect fungi development, given that $B$. cinerea poses effective ROS-detoxification systems, while at the same time $B$. cinerea can even contribute to ROS increase by producing its own ROS [50,51]. The rapid accumulation of $\mathrm{H}_{2} \mathrm{O}_{2}$ observed (Figure 1), is a widespread defense mechanism of higher plants against pathogen attack [50].

Non-photochemical chlorophyll fluorescence quenching (NPQ), the key photoprotective process in plants that dissipates excess light energy as heat and protects photosynthesis $[11,12,53-56]$, increased significantly up to $120 \mathrm{~min}$ after spore suspension application, but later on decreased to control level (Figure 5a). Similarly, NPQ increased in ice leaves in the surrounding area of the infection by B. cinerea [24]. After $240 \mathrm{~min}$ of B. cinerea spore suspension application, NPQ at HL was significantly lower than the control (Figure $5 b$ ). This indicates that when Botrytis application was combined with HL, the photoprotective mechanism was no longer buffering the excess light stress levels, indicating an imbalance between energy supply and demand [57-60]. This, results in increased ${ }^{1} \mathrm{O}_{2}$ and $\mathrm{H}_{2} \mathrm{O}_{2}$ production [61] as we observed (Figures $1 \mathrm{~b}$ and $4 \mathrm{~b}$ ) respectively. Non-photochemical quenching is a major component of the systemic acquired acclimation and systemic acquired resistance which is tightly related to ROS [10,56]. Chloroplasts through the operation of photosynthesis play an important role as redox sensors of environmental conditions and elicit acclimatory or stress defense responses $[62,63]$. Tomato leaflets after $B$. cinerea spore suspensions application show an increased capacity to keep quinone (QA) oxidized, thus, to have a higher fraction of open PSII reaction centers $\left(q_{\mathrm{P}}\right)$ compared to controls (Figure 7), indicating an enhanced PSII functionality.

At $30 \mathrm{~min}$ after spore suspensions application, a decreased $\Phi_{\mathrm{PSII}}$ in the direct vicinity of the application spot compared to control values was detected (Figure 6), while at the surrounding area and the rest of the leaflet, an increased $\Phi_{\mathrm{PSII}}$ was observed, specifying that the biotic stress was signaled to the rest of the leaflet regions, distant from the spore application area, having as a result a higher $\Phi_{\mathrm{PSII}}$ value at the whole leaflet compared to control. It has been frequently shown that $\mathrm{H}_{2} \mathrm{O}_{2}$ diffuses through leaf veins to act as a long-distance molecule, triggering the stress defense response in plants $[9,12,14,16,23]$. An inhibition of photosynthesis by decreased $\Phi_{\mathrm{PSII}}$ values in the direct vicinity of the $B$. cinerea infection sites of tomato leaflets was recorded [64], but, with no alterations in the primary metabolism in the rest of the leaf tissue [64]. Decays in the effective quantum yield of PSII photochemistry $\left(\Phi_{\mathrm{PSII}}\right)$ and increases in NPQ values before any visual symptoms appeared were observed in cashew seedlings inoculated with Lasiodiplodia theobromae [65].

The enhancement of $\Phi_{\text {PSII }} 30 \mathrm{~min}$ after B. cinerea spore application (Figure 2) and the concurrent increase of the regulated non-photochemical energy loss in PSII ( $\left.\Phi_{\mathrm{NPQ}}\right)$ (Figure 3), resulted in a significant decrease in the quantum yield of non-regulated energy loss in PSII ( $\Phi_{\mathrm{NO}}$ ) (Figure 4$)$. $\Phi_{\mathrm{NO}}$ comprises of chlorophyll fluorescence internal conversions and intersystem crossing, that results to ${ }^{1} \mathrm{O}_{2}$ formation via the triplet state of chlorophyll $\left({ }^{3} \mathrm{chl}^{*}\right)[53,66-68]$. Thus, after application of $B$. cinerea on tomato leaflets, the decreased $\Phi_{\mathrm{NO}}$ indicates decreased ${ }^{1} \mathrm{O}_{2}$, that is considered as a highly damaging ROS 
produced by PSII [14,69-72]. However, $240 \mathrm{~min}$ after $B$. cinerea application, the increased $\Phi_{\mathrm{NO}}$ suggests high levels of ${ }^{1} \mathrm{O}_{2}$ (Figure 4) that could act synergistically with the high $\mathrm{H}_{2} \mathrm{O}_{2}$ level (Figure 1d), in chloroplast damage [15,73]. Botrytis cinerea is a necrotrophic fungus that produces constantly toxic compounds which ultimately cause cell death [4]. Then, the fungus feeds on the dead tissue, thus, causing noticeable necrotic lesions [4].

While ${ }^{1} \mathrm{O}_{2}$ creation via ${ }^{3} \mathrm{chl}^{*}$ decreased $30 \mathrm{~min}$ after spore application compared to control (Figure $4 \mathrm{a}$ ), $\mathrm{H}_{2} \mathrm{O}_{2}$ was detected to appear $30 \mathrm{~min}$ after spore application (Figure 1c), and gradually to increase (Figure 1d). Hydrogen peroxide levels were positively correlated with disease severity [74], and low hydrogen peroxide levels appear to be the best indicator for leaf resistance to B. cinerea in strawberry leaves [74], while, chloroplast-generated ROS play a major role in $B$. cinerea -induced leaf damage [73], that eventually results in cell death (necrosis) [4]. As ROS formation by energy transfer $\left({ }^{1} \mathrm{O}_{2}\right)$, and electron transport $\left(\mathrm{H}_{2} \mathrm{O}_{2}\right)$ is simultaneous, it seems likely that their signaling pathways occasionally antagonize each other [13]. A low increase in ROS level is considered as favorable for activating defense responses $[13,50,75,76]$, but an excessive ROS level is damaging to PSII functionality $[9,13]$, which seems to be the case in our experimentation.

Botrytis cinerea that has been placed second in rank order of the top 10 fungal plant pathogens [77] can develop microscopic infections in epidermal cells of leaves that remain hidden for a certain period but after sporulation they convert in sources of primary inoculum and spread to other tissues [74].

The enhanced PSII functionality $30 \mathrm{~min}$ after Botrytis application can possible be related with the need of an increased sugar production that is associated with a stronger plant defense potential through the induction of defense genes [7]. However, increased levels of soluble sugars have been shown to support B. cinerea growth in tomato leaves [6]. In Rosa chinensis leaves, exogenous jasmonate (JA) spraying was shown to be essential for inducing defense response against $B$. cinerea [5]. Plant defenses can be activated by ROS [50], or by elicitor molecules such as chitosan [78], and $\gamma$-aminobutyric acid (GABA) [79], that are able to induce resistance mechanisms against $B$. cinerea.

Photosystem II responses of tomato leaflets to $B$. cinerea inoculation can be described as a time-dependent hormetic response (Figure 8) in terms of "stress defense response" and "toxicity" $[76,80]$. Activation by a low-dose effect or short-time exposure is a common phenomenon that is associated with the term "hormesis", typically indicating a positive biological response $[13,44,55,81-86]$. There are published studies reporting a time-dependent hormesis $[55,82]$, but it is only recently that analysis has been made regarding the features of hormesis as a function of time $[13,81,82]$, and according to our data, under biotic stress.

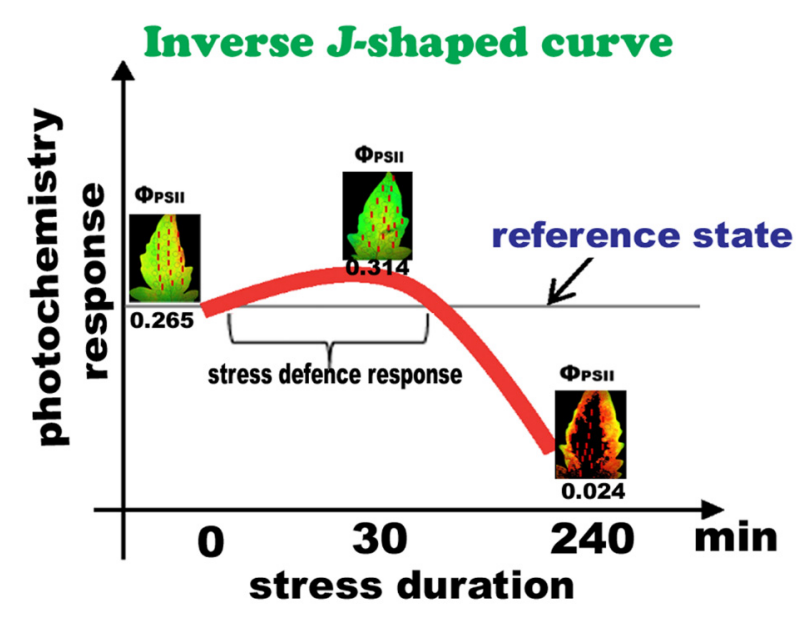

Figure 8. Overview of the hormetic response of photosystem II in tomato (at moderate light intensity), to $B$. cinerea spore application. The hormetic effect is defined by an inverse $J$-shaped biphasic curve with a short exposure time to have a stimulatory effect but at longer exposure time severe toxic effects to be apparent. 


\section{Materials and Methods}

\subsection{Plant Material and Growth Conditions}

Tomato (Solanum lycopersicum L.) plants ( $20 \mathrm{~cm}$ in height) were obtained from the market and transported to a growth chamber with $20 \pm 1 / 18 \pm 1^{\circ} \mathrm{C}$ day/night temperature, 10-h photoperiod with photosynthetic photon flux density (PPFD) $220 \pm 20 \mu \mathrm{mol}$ quanta $\mathrm{m}^{-2} \mathrm{~s}^{-1}$ and relative humidity $50 \pm 5 / 60 \pm 5 \%$ day/night.

\subsection{Pathogen Culture and Spore Suspension Application}

Botrytis cinerea ATHUM 4850 obtained from the ATHUM Culture Collection of Fungi of the National and Kapodistrian University of Athens Mycetotheca was used for tomato leaf spore application and was cultured on a solid nutrient medium (Potato Dextrose Agar, PDA, BD Difco, Oxford, UK) containing $0.5 \mathrm{~mL} \mathrm{~L}^{-1}$ lactic acid $1 \mathrm{~N}$ at $23{ }^{\circ} \mathrm{C}$ until sporulation. Sporulated cultures were transferred in $100 \mathrm{~mL}$ sterilized distilled water and gently vortexed for spore release.

Tomato 5th leaflets were detached and laid on Petri dishes containing two sterilized blotting filter papers (Whatman, Schleicher and Schuell, Ottawa, Canada), wetted with sterile water. A drop $(20 \mu \mathrm{L})$ of $B$. cinerea aqueous spore suspension $\left(10^{5}-10^{7}\right.$ spores $\left./ \mathrm{mL}\right)$ was applied on tomato leaflets with a micropipette [87] as shown on Figure 1a, while leaves treated with a drop $(20 \mu \mathrm{L})$ of sterile water (without $B$. cinera spores) were considered as controls.

\subsection{Hydrogen Peroxide Imaging Detection}

$\mathrm{H}_{2} \mathrm{O}_{2}$ imaging detection, in control, and at 30,120, and 240 min after spore suspension application, was performed as described earlier [12]. Briefly, inoculated and non-inoculated tomato leaflets were incubated with $25 \mu \mathrm{M} \mathrm{2} 2^{\prime}, 7^{\prime}$-dichlorofluorescein diacetate (DCF-DA, Sigma-Aldrich, Chemie GmbH, Schnelldorf, Germany) for $30 \mathrm{~min}$ in the dark, to visualize $\mathrm{H}_{2} \mathrm{O}_{2}$ production.many

Inoculated and control tomato leaflets were observed under a Zeiss Axioplan epifluoresence microscope equipped with an AxioCam MRc 5 digital camera. Photographs were obtained with the ZEN 2 version software according to the manufacturer's instructions.

\subsection{Chlorophyll Fluorescence Imaging Analysis}

An Imaging PAM M-Series system (Heinz Walz Instruments, Effeltrich, Germany) was used for the chlorophyll fluorescence measurements of the dark adapted (15 min) control and infected tomato leaflets as described in detail previously [39]. Measurements were conducted in leaves treated with a drop $(20 \mu \mathrm{L})$ of sterile water (without B. cinera spores, control, $0 \mathrm{~min}$ ) and after 30, 120 and $240 \mathrm{~min}$ of $B$. cinerea aquatic spore suspension application. The light intensities that were used for the photosynthetic efficiency measurements were $230 \mu \mathrm{mol}$ photons $\mathrm{m}^{-2} \mathrm{~s}^{-1}$, a low light (LL) intensity similar to the growth light, a moderate light (ML) intensity at $640 \mu \mathrm{mol}$ photons $\mathrm{m}^{-2} \mathrm{~s}^{-1}$, and a high light (HL) one, at $900 \mu \mathrm{mol}$ photons $\mathrm{m}^{-2} \mathrm{~s}^{-1}$. Representative areas of interest (AOIs) were selected in each leaflet so as to cover the whole leaflet area. The chlorophyll fluorescence parameters that were measured together with their definitions are shown in Table 1. Color-coded images of the effective quantum yield of PSII photochemistry $\left(\Phi_{\mathrm{PSII}}\right)$ and the redox state of the plastoquinone pool $\left(q_{\mathrm{P}}\right)$, obtained at ML intensity at $640 \mu \mathrm{mol}$ photons $\mathrm{m}^{-2} \mathrm{~s}^{-1}$, are also presented. 
Table 1. Definitions of the chlorophyll fluorescence parameters and their calculation.

\begin{tabular}{ccc}
\hline Parameter & \multicolumn{1}{c}{ Definition } & Calculation \\
\hline$\Phi_{\mathrm{PSII}}$ & $\begin{array}{c}\text { The effective quantum yield of PSII } \\
\text { photochemistry }\end{array}$ & $\left(\mathrm{Fm}^{\prime}-\mathrm{Fs}\right) / \mathrm{Fm}^{\prime}$ \\
\hline$\Phi_{\mathrm{NPQ}}$ & $\begin{array}{c}\text { The quantum yield of regulated } \\
\text { non-photochemical energy loss in PSII, that } \\
\text { is heat dissipation for photoprotection }\end{array}$ & Fs $/ \mathrm{Fm}^{\prime}-\mathrm{Fs} / \mathrm{Fm}$ \\
\hline $\mathrm{NPQ}$ & $\begin{array}{c}\text { The quantum yield of non-regulated energy } \\
\text { loss in PSII }\end{array}$ & Fs $/ \mathrm{Fm}_{\mathrm{NO}}$ \\
\hline$q_{\mathrm{P}}$ & $\begin{array}{c}\text { The non-photochemical quenching that } \\
\text { reflects heat dissipation of excitation energy } \\
\text { The photochemical quenching, that is the } \\
\text { redox state of the plastoquinone pool, is a } \\
\text { measure of the number of open PSII } \\
\text { reaction centers }\end{array}$ & $\left(\mathrm{Fm}^{\prime}-\mathrm{Fs}\right) /\left(\mathrm{Fm}^{\prime}-\mathrm{Fo}^{\prime}\right) / \mathrm{Fm}^{\prime}$ \\
\hline
\end{tabular}

\subsection{Statistics}

Statistically significant differences among the means were determined, from three independent treatments with each treatment consisting of three leaflets from three different tomato plants, using two-way ANOVA. Means $( \pm$ SD) were considered statistically different at a level of $p<0.05$.

\section{Conclusions}

In the present study, $30 \mathrm{~min}$ after application of Botrytis spore suspension in tomato leaflets, before any visual symptoms appeared, defense response mechanisms were triggered, with light energy use to be adjusted by NPQ in a such way that PSII functionality to be enhanced. The underlying mechanism involved was possible activated by $\mathrm{H}_{2} \mathrm{O}_{2}$, that was detected $30 \mathrm{~min}$ after Botrytis application with an increasing trend up to $240 \mathrm{~min}$. This, is possibly convening tolerance against $B$. cinerea at short-time exposure, but at relatively longer exposure time when $\mathrm{H}_{2} \mathrm{O}_{2}$ is increasing, it is becoming a damaging molecule. Hence, the response of tomato PSII to $B$. cinerea, indicates a hormetic temporal response, in terms of "stress defense response" and "toxicity", expanding the features of hormesis to biotic factors also.

Author Contributions: Conceptualization, I.-D.S.A. and M.M.; methodology, M.-L.S., I.S., I.P. and I.-D.S.A.; software, M.-L.S., I.S., I.P. and M.M.; validation, I.P., I.-D.S.A. and M.M.; formal analysis, I.-D.S.A., I.S., I.P. and M.M.; investigation, M.-L.S., I.S., I.P. and I.-D.S.A.; resources, I.S., I.P., I.-D.S.A. and M.M.; data curation, M.-L.S., I.S., I.P., I.-D.S.A. and M.M.; writing-original draft preparation, I.-D.S.A. and M.M.; writing-review and editing, I.S., I.P., I.-D.S.A. and M.M.; visualization, I.-D.S.A. and M.M.; supervision, I.S., I.-D.S.A. and M.M.; project administration, I.S., I.-D.S.A. and M.M.; funding acquisition, I.S., I.P., I.-D.S.A. and M.M.; All authors have read and agreed to the published version of the manuscript.

Funding: M.-L.S. was partly supported by the internship program of the National and Kapodistrian University of Athens, mis code 5032778, operational program "Competitiveness-Entrepreneurship \& Innovation 2014-2020", ESPA partnership agreements 2014-2020.

Institutional Review Board Statement: Not applicable.

Informed Consent Statement: Not applicable.

Data Availability Statement: No new data were created or analyzed in this study. Data sharing is not applicable to this article.

Conflicts of Interest: The authors declare no conflict of interest. 


\section{References}

1. Yu, W.; Zhao, R.; Sheng, J.; Shen, L. SlERF2 is associated with methyl jasmonate-mediated defense response against Botrytis cinerea in tomato fruit. J. Agric. Food Chem. 2018, 66, 9923-9932. [CrossRef]

2. Hou, R.; Shi, J.; Ma, X.; Wei, H.; Hu, J.; Tsang, Y.F.; Gao, M.T. Effect of phenolic acids derived from rice straw on Botrytis cinerea and infection on tomato. Waste Biomass Valor. 2020, 11, 6555-6563. [CrossRef]

3. Cristescu, S.M.; De Martinis, D.; Hekkert, S.L.; Parker, D.H.; Harren, F.J.M. Ethylene production by Botrytis cinerea in vitro and in tomatoes. Appl. Environ. Microbiol. 2002, 68, 5342-5350. [CrossRef]

4. Williamson, B.; Tudzynski, B.; Tudzynski, P.; van Kan, J.A. Botrytis cinerea: The cause of grey mould disease. Mol. Plant Pathol. 2007, 8, 561-580. [CrossRef]

5. Ren, H.; Bai, M.; Sun, J.; Liu, J.; Ren, M.; Dong, Y.; Wang, N.; Ning, G.; Wang, C. RcMYB84 and RcMYB123 mediate jasmonateinduced defense responses against Botrytis cinerea in rose (Rosa chinensis). Plant J. 2020, 103, 1839-1849. [CrossRef]

6. Courbier, S.; Grevink, S.; Sluijs, E.; Bonhomme, P.O.; Kajala, K.; Van Wees, S.C.M.; Pierik, R. Far-red light promotes Botrytis cinerea disease development in tomato leaves via jasmonate-dependent modulation of soluble sugars. Plant Cell Environ. 2020, 43, 2769-2781. [CrossRef]

7. Moghaddam, M.R.B.; Van Den Ende, W. Sugars and plant innate immunity. J. Exp. Bot. 2012, 63, 3989-3998. [CrossRef]

8. Valeri, M.C.; Novi, G.; Weits, D.A.; Mensuali, A.; Perata, P.; Loreti, E. Botrytis cinerea induces local hypoxia in Arabidopsis leaves. New Phytol. 2021, 229, 173-185. [CrossRef]

9. Mittler, R. ROS are good. Trends Plant Sci. 2017, 22, 11-19. [CrossRef]

10. Czarnocka, W.; Karpiński, S. Friend or foe? Reactive oxygen species production, scavenging and signaling in plant response to environmental stresses. Free. Radic. Biol. Med. 2018, 122, 4-20. [CrossRef]

11. Moustaka, J.; Moustakas, M. Photoprotective mechanism of the non-target organism Arabidopsis thaliana to paraquat exposure. Pest. Biochem. Physiol. 2014, 111, 1-6. [CrossRef]

12. Moustaka, J.; Tanou, G.; Adamakis, I.D.; Eleftheriou, E.P.; Moustakas, M. Leaf age dependent photoprotective and antioxidative mechanisms to paraquat-induced oxidative stress in Arabidopsis thaliana. Int. J. Mol. Sci. 2015, 16, 13989-14006. [CrossRef]

13. Adamakis, I.-D.S.; Sperdouli, I.; Hanć, A.; Dobrikova, A.; Apostolova, E.; Moustakas, M. Rapid hormetic responses of photosystem II photochemistry of clary sage to cadmium exposure. Int. J. Mol. Sci. 2021, 22, 41. [CrossRef]

14. Moustaka, J.; Tanou, G.; Giannakoula, A.; Adamakis, I.D.S.; Panteris, E.; Eleftheriou, E.P.; Moustakas, M. Anthocyanin accumulation in poinsettia leaves and its functional role in photo-oxidative stress. Environ. Exp. Bot. 2020, 175, 104065. [CrossRef]

15. Kuźniak, E.; Swiercz, U.; Chojak, J.; Sekulska-Nalewajko, J.; Gocławski, J. Automated image analysis for quantification of histochemical detection of reactive oxygen species and necrotic infection symptoms in plant leaves. J. Plant Interact. 2014, 9, 167-174. [CrossRef]

16. Adamakis, I.D.S.; Sperdouli, I.; Eleftheriou, E.P.; Moustakas, M. Hydrogen peroxide production by the spot-like mode action of bisphenol A. Front. Plant Sci. 2020, 11, 1196. [CrossRef]

17. Adamakis, I.D.S.; Malea, P.; Sperdouli, I.; Panteris, E.; Kokkinidi, D.; Moustakas, M. Evaluation of the spatiotemporal effects of bisphenol A on the leaves of the seagrass Cymodocea nodosa. J. Hazard. Mater. 2021, 404, 124001. [CrossRef]

18. Barbagallo, R.P.; Oxborough, K.; Pallett, K.E.; Baker, N.R. Rapid noninvasive screening for perturbations of metabolism and plant growth using chlorophyll fluorescence imaging. Plant Physiol. 2003, 132, 485-493. [CrossRef]

19. Kalaji, M.H.; Goltsev, V.N.; Żuk-Golaszewska, K.; Zivcak, M.; Brestic, M. Chlorophyll Fluorescence: Understanding Crop PerformanceBasics and Applications, 1st ed.; CRC Press: Boca Raton, FL, USA, 2017; p. 236, ISBN 9781315153605.

20. Sperdouli, I.; Moustakas, M. Spatio-temporal heterogeneity in Arabidopsis thaliana leaves under drought stress. Plant Biol. 2012, 14, 118-128. [CrossRef]

21. Bayçu, G.; Moustaka, J.; Gevrek-Kürüm, N.; Moustakas, M. Chlorophyll fluorescence imaging analysis for elucidating the mechanism of photosystem II acclimation to cadmium exposure in the hyperaccumulating plant Noccaea caerulescens. Materials 2018, 11, 2580. [CrossRef]

22. Moustakas, M.; Hanć, A.; Dobrikova, A.; Sperdouli, I.; Adamakis, I.D.S.; Apostolova, E. Spatial heterogeneity of cadmium effects on Salvia sclarea leaves revealed by chlorophyll fluorescence imaging analysis and laser ablation inductively coupled plasma mass spectrometry. Materials 2019, 12, 2953. [CrossRef]

23. Sperdouli, I.; Moustaka, J.; Antonoglou, O.; Adamakis, I.-D.S.; Dendrinou-Samara, C.; Moustakas, M. Leaf age-dependent effects of foliar-sprayed CuZn nanoparticles on photosynthetic efficiency and ROS generation in Arabidopsis thaliana. Materials 2019, 12, 2498. [CrossRef]

24. Sekulska-Nalewajko, J.; Kornaś, A.; Gocławski, J.; Miszalski, Z.; Kuźniak, E. Spatial referencing of chlorophyll fluorescence images for quantitative assessment of infection propagation in leaves demonstrated on the ice plant: Botrytis cinerea pathosystem. Plant Methods 2019, 15, 18. [CrossRef]

25. Papadakis, I.E.; Giannakoula, A.; Therios, I.; Moustakas, M.; Nastou, A. Photosystem 2 activity of Citrus volkameriana (L.) leaves as affected by Mn nutrition and irradiance. Photosynthetica 2007, 45, 208-213. [CrossRef]

26. Asfi, M.; Ouzounidou, G.; Panajiotidis, S.; Therios, I.; Moustakas, M. Toxicity effects of olive-mill wastewater on growth, photosynthesis and pollen morphology of spinach plants. Ecotoxicol. Environ. Saf. 2012, 80, 69-75. [CrossRef]

27. Asfi, M.; Ouzounidou, G.; Moustakas, M. Evaluation of olive oil mill wastewater toxicity on spinach. Environ. Sci. Pollut. Res. 2012, 19, 2363-2371. [CrossRef] [PubMed] 
28. Murchie, E.H.; Lawson, T. Chlorophyll fluorescence analysis: A guide to good practice and understanding some new applications. J. Exp. Bot. 2013, 64, 3983-3998. [CrossRef]

29. Guidi, L.; Calatayud, A. Non-invasive tools to estimate stress-induced changes in photosynthetic performance in plants inhabiting Mediterranean areas. Environ. Exp. Bot. 2014, 103, 42-52. [CrossRef]

30. Sperdouli, I.; Moustakas, M. Differential blockage of photosynthetic electron flow in young and mature leaves of Arabidopsis thaliana by exogenous proline. Photosynthetica 2015, 53, 471-477. [CrossRef]

31. Kalaji, H.M.; Jajoo, A.; Oukarroum, A.; Brestic, M.; Zivcak, M.; Samborska, I.A.; Cetner, M.D.; Łukasik, I.; Goltsev, V.; Ladle, R.J. Chlorophyll a fluorescence as a tool to monitor physiological status of plants under abiotic stress conditions. Acta Physiol. Plant. 2016, 38, 1-11. [CrossRef]

32. Moustaka, J.; Ouzounidou, G.; Bayçu, G.; Moustakas, M. Aluminum resistance in wheat involves maintenance of leaf Ca ${ }^{2+}$ and $\mathrm{Mg}^{2+}$ content, decreased lipid peroxidation and $\mathrm{Al}$ accumulation, and low photosystem II excitation pressure. BioMetals 2016, 29, 611-623. [CrossRef]

33. Moustaka, J.; Ouzounidou, G.; Sperdouli, I.; Moustakas, M. Photosystem II is more sensitive than photosystem I to $\mathrm{Al}^{3+}$ induced phytotoxicity. Materials 2018, 11, 1772. [CrossRef]

34. Sperdouli, I.; Moustakas, M. Differential response of photosystem II photochemistry in young and mature leaves of Arabidopsis thaliana to the onset of drought stress. Acta Physiol. Plant. 2012, 34, 1267-1276. [CrossRef]

35. Moustakas, M.; Bayçu, G.; Sperdouli, I.; Eroğlu, H.; Eleftheriou, E.P. Arbuscular mycorrhizal symbiosis enhances photosynthesis in the medicinal herb Salvia fruticosa by improving photosystem II photochemistry. Plants 2020, 9, 962. [CrossRef]

36. Meng, L.; Mestdagh, H.; Ameye, M.; Audenaert, K.; Höfte, M.; Van Labeke, M.C. Phenotypic variation of Botrytis cinerea isolates is influenced by spectral light quality. Front. Plant Sci. 2020, 11, 1233. [CrossRef]

37. Pérez-Bueno, M.L.; Pineda, M.; Barón, M. Phenotyping plant responses to biotic stress by chlorophyll fluorescence imaging. Front. Plant Sci. 2019, 10, 1135. [CrossRef] [PubMed]

38. Moustakas, M.; Bayçu, G.; Gevrek-Kürüm, N.; Moustaka, J.; Csatári, I.; Rognes, S.E. Spatiotemporal heterogeneity of photosystem II function during acclimation to zinc exposure and mineral nutrition changes in the hyperaccumulator Noccaea caerulescens. Environ. Sci. Pollut. Res. 2019, 26, 6613-6624. [CrossRef] [PubMed]

39. Moustaka, J.; Panteris, E.; Adamakis, I.D.S.; Tanou, G.; Giannakoula, A.; Eleftheriou, E.P.; Moustakas, M. High anthocyanin accumulation in poinsettia leaves is accompanied by thylakoid membrane unstacking, acting as a photoprotective mechanism, to prevent ROS formation. Environ. Exp. Bot. 2018, 154, 44-55. [CrossRef]

40. Agathokleous, E. Environmental hormesis, a fundamental non-monotonic biological phenomenon with implications in ecotoxicology and environmental safety. Ecotoxicol. Environ. Saf. 2018, 148, 1042-1053. [CrossRef]

41. Christou, A.; Michael, C.; Fatta-Kassinos, D.; Fotopoulos, V. Can the pharmaceutically active compounds released in agroecosystems be considered as emerging plant stressors? Environ. Int. 2018, 114, 360-364. [CrossRef]

42. Muszynska, E.; Labudda, M. Dual role of metallic trace elements in stress biology-from negative to beneficial impact on plants. Int. J. Mol. Sci. 2019, 20, 3117. [CrossRef]

43. Agathokleous, E.; Feng, Z.; Peñuelas, J. Chlorophyll hormesis: Are chlorophylls major components of stress biology in higher plants? Sci. Total Environ. 2020, 726, 138637. [CrossRef] [PubMed]

44. Małkowski, E.; Sitko, K.; Szopiński, M.; Gieroń, Z.; Pogrzeba, M.; Kalaji, H.M.; Zieléznik-Rusinowska, P. Hormesis in plants: The role of oxidative stress, auxins and photosynthesis in corn treated with Cd or Pb. Int. J. Mol. Sci. 2020, 21, 2099. [CrossRef]

45. Rozhko, T.V.; Nogovitsyna, E.I.; Badun, G.A.; Lukyanchuk, A.N.; Kudryasheva, N.S. Reactive Oxygen Species and low-dose effects of tritium on bacterial cells. J. Environ. Radioact. 2019, 208-209, 106035. [CrossRef]

46. Malea, P.; Charitonidou, K.; Sperdouli, I.; Mylona, Z.; Moustakas, M. Zinc uptake, photosynthetic efficiency and oxidative stress in the seagrass Cymodocea nodosa exposed to ZnO nanoparticles. Materials 2019, 12, 2101. [CrossRef]

47. Roach, T.; Na, C.S.; Stöggl, W.; Krieger-Liszkay, A. The non-photochemical quenching protein LHCSR3 prevents oxygendependent photoinhibition in Chlamydomonas reinhardtii. J. Exp. Bot. 2020, 71, 2650-2660. [CrossRef]

48. Nishiyama, Y.; Yamamoto, H.; Allakhverdiev, S.I.; Inaba, M.; Yokota, A.; Murata, N. Oxidative stress inhibits the repair of photodamage to the photosynthetic machinery. EMBO J. 2001, 20, 5587-5594. [CrossRef] [PubMed]

49. Agathokleous, E.; Kitao, M.; Calabrese, E.J. Hormesis: A compelling platform for sophisticated plant science. Trends Plant Sci. 2019, 24, 318-327. [CrossRef]

50. Rolke, Y.; Liu, S.; Quidde, T.; Williamson, B.; Schouten, A.; Weltring, K.M.; Siewers, V.; Tenberge, K.B.; Tudzynski, B.; Tudzynski, P. Functional analysis of $\mathrm{H}_{2} \mathrm{O}_{2}$-generating systems in Botrytis cinerea: The major Cu-Zn-superoxide dismutase (BCSOD1) contributes to virulence on French bean, whereas a glucose oxidase (BCGOD1) is dispensable. Mol. Plant Pathol. 2004, 5, 17-27. [CrossRef]

51. Hua, L.; Yong, C.; Zhanquan, Z.; Boqiang, L.; Guozheng, Q.; Shiping, T. Pathogenic mechanisms and control strategies of Botrytis cinerea causing post-harvest decay in fruits and vegetables. Food Qual. Saf. 2018, 3, 111-119. [CrossRef]

52. Colmenares, A.J.; Aleu, J.; Durán-Patrón, R.; Collado, I.G.; Hernández-Galán, R. The putative role of botrydial and related metabolites in the infection mechanism of Botrytis cinerea. J. Chem. Ecol. 2002, 28, 997-1005. [CrossRef]

53. Müller, P.; Li, X.P.; Niyogi, K.K. Non-photochemical quenching. A response to excess light energy. Plant Physiol. 2001, 125, 1558-1566. [CrossRef]

54. Ruban, A.V. Nonphotochemical chlorophyll fluorescence quenching: Mechanism and effectiveness in protecting plants from photodamage. Plant Physiol. 2016, 170, 1903-1916. [CrossRef] [PubMed] 
55. Agathokleous, E.; Kitao, M.; Harayama, H. On the nonmonotonic, hormetic photoprotective response of plants to stress. Dose-Response 2019, 17, 1-3. [CrossRef] [PubMed]

56. Vitale, L.; Vitale, E.; Costanzo, G.; De Maio, A.; Arena, C. Photo-protective mechanisms and the role of poly (ADP-ribose) polymerase activity in a facultative CAM plant exposed to long-term water deprivation. Plants 2020, 9, 1192. [CrossRef] [PubMed]

57. Külheim, C.; Ågren, J.; Jansson, S. Rapid regulation of light harvesting and plant fitness in the field. Science 2002, 297, 91-93. [CrossRef] [PubMed]

58. Li, X.; Müller-Moulé, P.; Gilmore, A.M.; Niyogi, K.K. PsbS-dependent enhancement of feedback de-excitation protects photosystem II from photoinhibition. Proc. Natl. Acad. Sci. USA 2002, 99, 15222-15227. [CrossRef] [PubMed]

59. Sperdouli, I.; Moustakas, M. Leaf developmental stage modulates metabolite accumulation and photosynthesis contributing to acclimation of Arabidopsis thaliana to water deficit. J. Plant Res. 2014, 127, 481-489. [CrossRef]

60. Sperdouli, I.; Moustakas, M. A better energy allocation of absorbed light in photosystem II and less photooxidative damage contribute to acclimation of Arabidopsis thaliana young leaves to water deficit. J. Plant Physiol. 2014, 171, 587-593. [CrossRef]

61. Dietz, K.J.; Pfannschmidt, T. Novel regulators in photosynthetic redox control of plant metabolism and gene expression. Plant Physiol. 2011, 155, 1477-1485. [CrossRef]

62. Li, Z.; Wakao, S.; Fischer, B.B.; Niyogi, K.K. Sensing and responding to excess light. Annu. Rev. Plant Biol. 2009, 60, 239-260. [CrossRef] [PubMed]

63. Gawronski, P.; Burdiak, P.; Scharff, L.B.; Mielecki, J.; Górecka, M.; Zaborowska, M.; Leister, D.; Waszczak, C.; Karpiński, S. CIA2 and CIA2-LIKE are required for optimal photosynthesis and stress responses in Arabidopsis thaliana. Plant J. 2021, 105, 619-638. [CrossRef] [PubMed]

64. Berger, S.; Papadopoulos, M.; Schreiber, U.; Kaiser, W.; Roits, T. Complex regulation of gene expression, photosynthesis and sugar levels by pathogen infection in tomato. Physiol. Plant. 2004, 122, 419-428. [CrossRef]

65. Muniz, C.R.; Freire, F.C.O.; Viana, F.M.P.; Cardoso, J.E.; Sousa, C.A.F.; Guedes, M.I.F.; van der Schoor, R.; Jalink, H. Monitoring cashew seedlings during interactions with the fungus Lasiodiplodia theobromae using chlorophyll fluorescence imaging. Photosynthetica 2014, 52, 529-537. [CrossRef]

66. Kasajima, I.; Ebana, K.; Yamamoto, T.; Takahara, K.; Yano, M.; Kawai-Yamada, M.; Uchimiya, H. Molecular distinction in genetic regulation of nonphotochemical quenching in rice. Proc. Natl. Acad. Sci. USA 2011, 108, 13835-13840. [CrossRef]

67. Gawroński, P.; Witoń, D.; Vashutina, K.; Bederska, M.; Betliński, B.; Rusaczonek, A.; Karpiński, S. Mitogen-activated protein kinase 4 is a salicylic acid-independent regulator of growth but not of photosynthesis in Arabidopsis. Mol. Plant 2014, 7, 1151-1166. [CrossRef]

68. Hideg, É.; Spetea, C.; Vass, I. Singlet oxygen production in thylakoid membranes during photoinhibition as detected by EPR spectroscopy. Photosynth. Res. 1994, 39, 191-199. [CrossRef]

69. Op den Camp, R.G.L.; Przybyla, D.; Ochsenbein, C.; Laloi, C.; Kim, C.; Danon, A.; Wagner, D.; Hideg, É.; Göbel, C.; Feussner, I.; et al. Rapid induction of distinct stress responses after the release of singlet oxygen in Arabidopsis. Plant Cell 2003, 15, $2320-2332$. [CrossRef] [PubMed]

70. Krieger-Liszkay, A.; Fufezan, C.; Trebst, A. Singlet oxygen production in photosystem II and related protection mechanism. Photosynth. Res. 2008, 98, 551-564. [CrossRef]

71. Triantaphylidès, C.; Havaux, M. Singlet oxygen in plants: Production, detoxification and signaling. Trends Plant Sci. 2009, 14, 219-228. [CrossRef] [PubMed]

72. Telfer, A. Singlet oxygen production by PSII under light stress: Mechanism, detection and the protective role of beta-carotene. Plant Cell Physiol. 2014, 55, 1216-1223. [CrossRef]

73. Rossi, F.R.; Krapp, A.R.; Bisaro, F.; Maiale, S.J.; Pieckenstain, F.L.; Carrillo, N. Reactive oxygen species generated in chloroplasts contribute to tobacco leaf infection by the necrotrophic fungus Botrytis cinerea. Plant J. 2017, 92, 761-773. [CrossRef] [PubMed]

74. Meng, L.; Höfte, M.; Van Labeke, M.C. Leaf age and light quality influence the basal resistance against Botrytis cinerea in strawberry leaves. Environ. Exp. Bot. 2019, 157, 35-45. [CrossRef]

75. Moustakas, M. The role of metal ions in biology, biochemistry and medicine. Materials 2021, 14, 549. [CrossRef] [PubMed]

76. Calabrese, E.J. Hormetic mechanisms. Crit. Rev. Toxicol. 2013, 43, 580-606. [CrossRef] [PubMed]

77. Dean, R.; Van Kan, J.A.; Pretorius, Z.A.; Hammond-Kosack, K.E.; Di Pietro, A.; Spanu, P.D.; Rudd, J.J.; Dickman, M.; Kahmann, R.; Ellis, J.; et al. The top 10 fungal pathogens in molecular plant pathology. Mol. Plant Pathol. 2012, 13, 414-430. [CrossRef] [PubMed]

78. De Vega, D.; Holden, N.; Hedley, P.E.; Morris, J.; Luna, E.; Newton, A. Chitosan primes plant defence mechanisms against Botrytis cinerea, including expression of Avr9/Cf-9 rapidly elicited genes. Plant Cell Environ. 2021, 44, 290-303. [CrossRef]

79. van Rensburg, H.C.J.; Van den Ende, W. Priming with $\gamma$-aminobutyric acid against Botrytis cinerea reshuffles metabolism and reactive oxygen species: Dissecting signalling and metabolism. Antioxidants 2020, 9, 1174. [CrossRef]

80. Agathokleous, E.; Calabrese, E.J. Hormesis: The dose response for the 21st Century: The future has arrived. Toxicology 2019, 425, 152249. [CrossRef]

81. Agathokleous, E.; Feng, Z.; Iavicoli, I.; Calabrese, E.J. The two faces of nanomaterials: A quantification of hormesis in algae and plants. Environ. Int. 2019, 131, 105044. [CrossRef]

82. Agathokleous, E.; Kitao, M.; Calabrese, E.J. Hormesis: Highly generalizable and beyond laboratory. Trends Plant Sci. 2020, 25, 1076-1086. [CrossRef] 
83. Calabrese, E.J. Hormesis: Path and progression to significance. Int. J. Mol. Sci. 2018, 19, 2871. [CrossRef] [PubMed]

84. Rozhko, T.V.; Nemtseva, E.V.; Gardt, M.V.; Raikov, A.V.; Lisitsa, A.E.; Badun, G.A.; Kudryasheva, N.S. Enzymatic responses to low-intensity radiation of tritium. Int. J. Mol. Sci. 2020, 21, 8464. [CrossRef] [PubMed]

85. Calabrese, E.J.; Agathokleous, E. Accumulator plants and hormesis. Environ. Pollut. 2021, 274, 116526. [CrossRef] [PubMed]

86. Małkowski, E.; Sitko, K.; Zieleźnik-Rusinowska, P.; Gieron, Ż.; Szopiński, M. Heavy metal toxicity: Physiological implications of metal toxicity in plants. In Plant Metallomics and Functional Omics; Sablok, G., Ed.; Springer: Cham, Switzerland, $2019 ;$;pp. 253-301.

87. Zhang, S.; Li, X.; Sun, Z.; Shao, S.; Hu, L.; Ye, M.; Shi, K. Antagonism between phytohormone signalling underlies the variation in disease susceptibility of tomato plants under elevated $\mathrm{CO}_{2}$. J. Exp. Bot. 2015, 66, 1951-1963. [CrossRef] 